\title{
The Adoption and Utilization of Electronic Business in Response to the Global Economy During COVID-19
}

\author{
Joseph Bamidele Awotunde, University of Ilorin, Nigeria \\ (iD) https://orcid.org/0000-0002-1020-4432 \\ Roseline Oluwaseun Ogundokun, Landmark University, Omu Aran, Nigeria \\ (iD) https://orcid.org/0000-0002-2592-2824 \\ Emmanuel Abidemi Adeniyi, Landmark University, Omu Aran, Nigeria \\ (iD) https://orcid.org/0000-0002-2728-0116 \\ Sanjay Misra, Covenant University, Nigeria \\ (iD) https://orcid.org/0000-0002-3556-9331 \\ Gbemisola Janet Ajamu, Landmark University, Omu Aran, Nigeria
}

\begin{abstract}
The COVID-19 epidemic has triggered unmatched impairment to businesses globally. There are unmeasurable financial influences in the short-term and long-term that have caused intangible destruction within businesses. This study investigates the adoption and utilization of e-business during COVID-19 by both organizations and the general populaces. The study used a questionnaire-based survey to collect data from top managers of business organizations and their clients. SPSS was used to analyze the adoption factors. The outcomes presented that embracing e-business can assist to reduce the spread of COVID-19 and can reduce the physical ways of doing business. The findings of this study will help strategy makers, companies, and officials in making better decisions on the implementation of e-business. This will reduce the rapid spread of community transmission since ordering goods and services can easily be done virtually without physical contact, which goes in line with the social distance policy and in return boosts the country's economy.
\end{abstract}

\section{KEYWORDS}

E-Business, E-Commerce, Efficacy, Information Technology, IT Expertise, Management Support

\section{INTRODUCTION}

The entire human civilization and all aspects of life globally are been hit by the coronavirus pandemic (Daniyal et al., 2020). All the key economic powers of the world such as the USA, China, Spain, Germany, Uk, France, Switzerland, South Korea, Turkey, Canada, and the Netherlands were hit brutally by Coronavirus in the last four months (Ogundokun et al., 2020; Abdin, 2020; Lukman et al., 2020). The whole world is stagnant and dormant for an unpredictable period due to the outbreak of the deadly COVID-19. Human movements, transportation, cross-country vehicle, commercial 
planes, and cargoes were all stopped literarily and idle irrespective of parks and garages. Every aspect of productions including technical, Human, mechanical, and technological were rendered inoperative and reduced greatly to an insignificant level. Investment worth the Trillion dollar was idle and unused and with no values from different ends. Hence, one could easily state that the COVID-19 impact on the economy has resulted in a deeper Global Financial crisis in the future to come. Since the consumption of essential commodities cannot be stopped, both businessmen and entrepreneurs must be ready to further their businesses respectively.

The crisis may deepen if the supply of essential products is stopped (Abdin, 2020). Hence, the adoption of Electronic Business (E-business) during the COVID-19 pandemic will guarantee the proper functioning of business during and after the crisis. Electronic commerce (e-commerce) and e-business possibly will open a lasting source of earnings for individuals, companies, and countries. Ensuring accountabilities in businesses through the use of digital technologies will also be an added advantage during this outbreak (Abdin, 2020). The use of E-business tools in materials procurement, receiving orders, receive new shipments, recall employees, distribution, and after-sale service among others, thereby successfully enhancing the economy of any nation. The emergence of internet technologies and their limitless worldwide impact was the starting point to progress businesses and entrepreneurship to an advanced level. E-business gives room to companies and sellers to sell without the need for setting up mortar and brick shops or stores. The E-business is an act of conducting business in online settings, even as the internet serves as an integrated environment that brings purchasers and vendors together (Turban et al., 2015). Ullman (2013) regards e-business in the categories of potential businesses been carried out over the network. Each website that can make money, or whose purpose is to make money can be classified in this group (Horch et al., 2017).

The major tool that has been adopted in e-business is nothing else than the electronic shop (E-shop). A store that is been carried out in the internet environment is referred to as E-shop (Kollmann et al., 2016; Turban et al., 2015). Presently, the development of the e-shop is made possible by the use of cost-free technologies (such as Woocommerce) which could easily be executed and transformed into content administrative schemes (Beleščák, 2014). Pilík (2013) states that new e-shops increase up to 800 every year in the Czech Republic alone, thus e-business is of great benefit for both minor and average scale organizations (Kartiwi et al., 2018). Rapid response and feedback to an emerging trend in the act of purchasing products are achieved by trading through modern technologies. Thanks to this possibility, more flexibility, and competitive advantages are given to both small and medium scale companies over the big cooperation (Cantú et al., 2014).

The COVID-19 outbreak will increase greatly the total number of people that use e-business thereby increasing the feasibility and visibility of such business. E-business is still in its initial stages and its acceptance by many companies is not definitive. To date, little or no work has been carried out to identify possible advantages and strengths and the costs of e-business implementation and usage of various organizations. Nevertheless, e-business corporate acceptance and the major impact of e-business adoption on company efficiency are less discussed. Consequently, more in-depth studies are required to classify the factors affecting e-business adoption, particularly during COVID-19. Therefore, this study aims to investigate the technical, structural, and human elements of e-business acceptance during COVID-19, by focusing on the subsequent goals:

1. To analyze the technical, organizational, and human factors influencing the adoption and use of e-business particularly during COVID-19, and their consequent effect on global economic performance.

2. Identifying the degree of significance of factors known for the global economy.

To attend to the study goals, a survey questionnaire was distributed to a total number of 150 respondents. A theoretical method was established situated on the concept of TechnologyOrganization-Environment (TOE) and "Human-Organization-Technology (HOT)". This research 
used the Statistical Package for the Social Sciences (SPSS) to evaluate the theoretical model and to estimate the degree of worth of significant factors influencing the implementation of e-business and its corresponding effect on organizational efficiency during COVID-19.

The rest of this research is structured as follows. The impact of E-business during the COVID-19 pandemic is presented in Section 2. In Section 3, the challenges of adoption e-business during COVID-19 are presented. Section 4 addressed the creation of a theoretical model and also demonstrates the methodology procedure which includes the SEM and ANFIS approach. Section 5 describes the tests, and the conclusions were given in Section 6. Finally, the study provided findings and consequences.

\section{THE IMPACT OF E-BUSINESS DURING COVID-19 PANDEMIC}

Within one month, the spread of the COVID-19 pandemic has changed shopping patterns around the world. The global consequences of coronavirus are uncontrollable and irresistible (Shahzad et al., 2020; Cohen \& Kupferschmidt, 2020). A greater number of nations are on restriction, stores are shut, institutions are locked, more than $90 \%$ of airline operations are suspended, despite all these restrictions, some companies are getting more order through electronic means (Odom, 2020; Shahzad et al., 2020). Globally, companies are increasingly heading towards digital transformation following the e-business dream of enhancing market efficiency (Shahzad et al., 2020). In this respect, the implementation of the electronic operating system will boost business efficiency. In recognizing this digital revolution, many nations have made tremendous efforts to plan the digital ecosystem to lead and train industries for transition (Shahzad et al., 2020).

The e-business has enhanced the performance and flexibility of commercial transactions, resulting in concentrated competition. Businesses will continuously adapt to emerging technology, incorporate newer and faster systems, and meet people's needs around the world throughout the COVID-19 epidemic. Competing companies must now work together to succeed, and must know that consumers are not far from purchasing from the next accessible vendor. When more people start using the Internet during the COVID-19 crisis, all businesses, whether already operating online or preparing to conduct some of their online business transactions, must understand the effect that internet-enabled business would have on customers and companies during this global epidemic.

A multitude of online storefronts populating the World Wide Web is now supplementing conventional "brick and mortar" stores. A single brick-and-mortar shop can sell 50,000 items, but an online shop can deliver an infinite number of them. Some apps would be a price comparison store, seeking the best offer on every good or service. There is an increasing amount of consumer data available which leads to better dealings for customers. Websites that post car invoice rates, for example, have allowed auto buyers to bypass the sticker price. Internet shopping has already started to dominate more conventional modes, according to research conducted during the 1999 Christmas season (Romm et al., 2002), which found higher online shopping satisfaction rates than shopping in brick-and-mortar stores or via catalogs. Customization makes browsing the Internet simpler and more fun for many users, knowing what they want. There are several advantages of having a company on the internet. Any e-business can deliver customized, high-quality customer service and enhanced operations management, strategic distribution network management, and supporting processes.

\section{THEORETICAL FRAMEWORK}

TOE was originally developed by Tornatzky et al. (1990) to consider the essential factors impacting the implementation of emerging technologies in organizations. In this system, any breakthrough can be expected from three different viewpoints such as infrastructure, climate, and organization. TOE is one of the most well-known ideas commonly used in numerous experiments on the implementation of technologies at the corporate level in diverse contexts (Baker, 2012). Technological factors from 
the TOE perspectives consist of an establishment's in-house and off-house technologies and include equipment and processes. The organizational point of view includes the characteristics, possessions, and characteristics, whereas the ecological point of view, comprises a company's functioning province and arrangement (Tornatzky et al., 1990). In turn, the HOT-fit principle was developed by combining "DeLone and McLean's IS Progress Model" and "Information Technology (IT) match model" for health information schemes (Yadegaridehkordi et al., 2020). Considering a full range of variables such as "person," "organization" and "technology," this approach seeks to improve the positive implementation of creativity in organizations. HOT-fit is versatile enough to adapt the life cycle of processes to various situations, stakeholder viewpoints, and evaluation approaches (Ahmadi et al., 2015, Yadegaridehkordi et al., 2020). This pattern has been widely used in different contexts and its use continues to expand in the literature on adoption (Lian et al., 2014; Yadegaridehkordi et al., 2020). While the definitions of HOT-fit and TOE are identical, the HOT-fit model includes the human experience which is not included in the TOE. Meanwhile, the TOE system is more effective when evaluating intra-firm acceptance of technologies as it considers environmental viewpoint (Oliveira \& Martins, 2011; Yadegaridehkordi et al., 2020). Thus, the combination of the TOE and HOT-fit model creates a holistic structure that takes into account all viewpoints and has thus been widely used for better organizational decision-making (Nilashi et al., 2016; Yadegaridehkordi et al., 2020). In the meantime, as the process of adopting innovation is very complex, a single theory is not enough to explain every aspect of this process (Yadegaridehkordi et al., 2020). The incorporation of Heat and TOE in this analysis is therefore a strong basis for concept creation.

TAM and TOE theories are aimed primarily at technology acceptance and are used to describe end-user adoption at the organizational level in many Information System (IS) studies. TAM's extensive emphasis on technology, to the exclusion of social and psychological variables (Agarwal \& Prasad, 1998; Venkatesh \& Bala, 2008), restricts its explanatory and predictive utility, necessitating incorporation with other frameworks (Awa et al., 2015; Dwivedi, et al., 2009). Ajzen's (1991) IDT and Rogers, Singhal, \& Quinlan, (2019) TPB attempted to compensate for TAM's shortcomings, however, their structures have yet to underpin as many studies in the contemporary IS domain as TOE's. The IDT paradigm explains acceptance by incorporating the constructs of organization and technology contexts, while TOE went a step further by incorporating the constructs of climate (Gangwar et al., 2014). The TOE paradigm is more holistic and size and business-friendly than other adoption frameworks (Wen \& Chen, 2010), has more empirical support in the IS area than other adoption frameworks like TAM, IDT, TRA, SM, and TPB (Henriksen, 2006; Hong et al., 2006; Kuan \& Chau, 2001; Yoon \& George, 2013; Zheng et al., 2011; Zhu et al., 2003) and meets the current scholarly need (Barrett et al., 2006; Jacobsson \& Linderoth, 2010; Venkatesh \& Bala, 2008) for more social interactive structures that resolve the ordeals of deterministic systems.

Many grounded adoption theories, such as TRA, IDT, and TPB, are useful in a variety of fields, but they don't focus as much on ICT acceptance as TAM and TOE constructs do (Moore \& Benbasat, 1991). In studying organizational level adoption, TOE is true, robust, and most dominant and unique (Gangwar et al., 2014; Awa et al., 2016) since its proposed generic factors provide more meaningful lenses for studying users' views about particular technologies, user adoption procedures, and implementation; foreseeing challenges; the technology's effect on the value chain and post-adoption diffusion; and the growth of organizational capabilities utilizing technology (Al-Natour \& Benbasat, 2009; Salwani et al., 2010). Figure 1 shows the conceptual research framework for the study.

\section{RESEARCH MODEL DEVELOPMENT}

This investigation attempts to introduce a 3D model built on technology, organization, and individual viewpoints from the perception of the TOE and HOT-fit model. For each aspect, the study identifies the most frequently relevant variables that have a major impact on e-business adoption. Complexity, usability, respective benefits, and rate of acceptance were clearly defined as technology-connected 


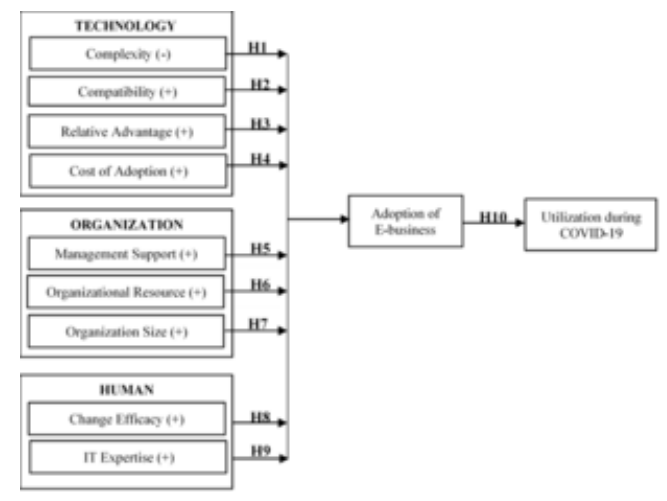

considerations that were addressed often in the choice of e-business adoption. Management assistance and organizational tools are known as the most often organizational elements that can positively impact the implementation of e-business. Shift success and IT experience are two individual qualities with a beneficial impact on e-business adoption.

\subsection{Technological Context}

Complexity is "the extent of interpretation of an invention as being fairly problematic to grasp and utilize" (Rogers, 2003). A higher degree of difficulty is assumed to trigger more trouble by using one or more assumed expertise (Kapoor et al., 2014). This consideration looks at the complexity involved with e-business use and its associated methods. Users might be worried about the troubles of adopting a technology (Shin, 2016). Investigators have regularly stated that uncertainty has a detrimental impact on the acceptance of innovation (Wang et al. 2016). Since e-business depends heavily on software for managing and analyzing vast volumes of data, high complexity is likely to slow its acceptance for it. Thus, the assumption is:

\section{H1: Complexity considered harms e-business adoption}

Compatibility is described as "the extent to which an invention is considered to be reliable with the beliefs, previous expectations, and requirements of prospective adopters" (Rogers, 2003). Adopting any breakthrough involves profound improvements in technological criteria and corporate principles (Verma et al., 2017). The use of e-business will also be following existing corporate IT tools and specifications. Innovations suit available technology and norms are adopted quicker than those that are not, according to Shin (2016). The significance of consistency in implementing innovation has been documented in various studies (Ahani et al., 2017; Verma et al., 2017). Therefore, it is believed that:

H2: Perceived reliability has a favorable impact on the adoption of eBusiness

The respective benefits are described as the extent to which an invention is considered to be improved than the concept it replaces (Sun et al., 2016). Factors such as strengthened networking incentives, expanded competition, and extra resources offered to consumers are investigated (Sun et al., 2016). According to Park et al. (2015), there is no incentive in companies to accept and use e-business without separating the advantages and potential costs. A relative advantage was identified as being a major predictor of acceptance of innovation (Maduku et al., 2016). Therefore, it is presumed: 
H3: Relative benefits have constructive impacts on e-business adoption

The amount of adopting e-business is referred to as the expenditure incurred by an enterprise to sustain the use of large data and impending scalability (Sun et al., 2016). For organizations to utilize e-business technology, a large investment is required in both hardware and software. Meanwhile, the expense of recruiting new workers and educating current employees is seen among other e-business implementation problems (Verma et al., 2017). Besides, the projected higher costs are expected to result in reductions in the desire to implement technologies (Wang et al., 2016). Thus, the assumption is:

H4: Adoption costs have a detrimental impact on the embrace of E-business

\subsection{Organizational Context}

Management support is described as the extent to which upper administration recognizes the significance of big data technologies and the level to which it engages in relevant programs" (Park et al., 2015). Robust administrative assistance can assist companies to navigate the difficulties and uncertainties involved with emerging innovations effectively and improve acceptance rates (Ramamurthy et al., 2008). Strong management establishes a supportive environment, has the necessary tools, and accelerates the corporate process of technological acceptance. The article has emphasized the significant function of management in the implementation of any product (Maduku et al., 2016). Thus, the assumption is:

H5: Support from management has a positive impact on e-business adoption

An organizational resource is referred to as the level to which the expertise, people, and business capitals of an enterprise are sufficient to aid implementation "(Powell \& Dent-Micallef, 1997). According to Verma et al. (2017), correct development organizations, systems, interfaces, and specifications in architecture should be planned for effective software acceptance. Technological preparation is currently one of the most important features affecting e-business acceptance in organizations (Park et al., 2015). Whereas, human capital appropriateness of ample IT capabilities is another requirement that should be stressed in the process of e-business adoption (Sun et al., 2016). Companies' conduct in accepting any technical advancement is heavily affected by the preparation and competency of existing technological, monetary, and people resources (Maduku et al., 2016). Therefore, it is believed that:

H6: Organizational tools have a beneficial impact on the implementation of e-Business

Organizational capacity is referred to as the yearly income of the firm and the sum of staff who could aid e-business acceptance" (Sun et al., 2016). The article has revealed the significant duty of organizational scale in embracing technologies (Hong and Zhu, 2006; Pan and Jang, 2008). It is clear that larger companies, as they have greater capital and can tolerate higher costs, are early adopters of any concept. Smaller companies, on the other hand, endure capital scarcity and experience several problems in handling the large assets essential for efficacious implementation (Sun et al., 2016). Thus, the assumption is:

H7: The size of a company has a favorable impact on e-commerce adoption 


\subsection{Human Context}

Change efficacy is "the degree to which leaders of the organization are trained internally and behaviorally to allow organizational transition" (Weiner et al., 2008). The introduction of e-business offers new opportunities for organizations, but the main vital factor in tackling the full benefits is organizational human readiness for change (Sun et al., 2016). The desire of managers to innovate dramatically affects optimistic attitudes and expectations in decisions to implement technologies (Petter et al., 2013). Meanwhile, a positive workplace climate will inspire workers to pursue new strategies without doubting that they would be penalized in an ineffective situation (Brock \& Khan, 2017). Therefore, corporate managers and workers in a company with a higher transition performance environment can better handle the improvements associated with e-business adoption and it is believed:

H8: Changing the use of e-business has a positive impact on the adoption

The definition of IT competence is that a company has ample employees with ample IT information to pursue an e-business (Powell \& Dent-Micallef, 1997). It is widely agreed that the presence of highly skilled and competent workers is a crucial feature shaping the implementation of technologies (Lucchetti \& Sterlacchini, 2004). In reality, the deficiency of sufficiently trained inside IT specialists creates weighty glitches and increased budgets as industries have to employ outside IT practitioners (Maduku et al., 2016). In e-business integration research in terms of "development preparation" and "IS expertise" (Kang \& Kim, 2015; Sun et al., 2016), the experience of IT workers has been widely observed and is thus believed to be:

H9: IT expertise has a beneficial impact on the implementation of e-business

\subsection{E-Business Adoption and Utilization During Covid-19}

Companies can display multiple trends in adopting emerging technologies that might inflict corresponding influences on their efficiency and competitive benefit (Voola et al., 2012). Therefore, usually, efficiency and technology adoption are jointly measured (Zepeda, 1994). Current research has increasingly documented a significant relationship between innovation adoption and the success of firms (Garrison et al., 2015; Voola et al., 2012). In the same perspective e-business is a driving factor for firm strategic advantage, which is comprised of more agile, reducing costs, growth, and innovation particularly during COVID-19. E-business raise firm services and revenues during COVID-19 in specific financial and non-financial aspect (Brock and Khan, 2017; Soon et al., 2016). Thus, it is assumed that:

H10: E-business adoption and utilization have a positive effect on firm services and sales.

\subsection{Questionnaire And Measurements}

The questionnaire was used in this investigation to generate responses from the respondents, and datasets were assembled from members of selected organizations. The principal strong point of the investigation instrument is its adaptability in explaining large populations' characters or sentiments (Blumberg et al. 2014). The questionnaire survey approach can determine causal interactions between factors and thus deliver widespread study opportunities (Pinsonneault \& Kraemer, 1993). Therefore, as a trustworthy method, several studies used a questionnaire to gather data from respondents (Akter et al., 2016; Lu \& Yang, 2014). The questionnaire was structured into two sections in this analysis. The first segment has concentrated on the demographic data of the respondents. The next section included concerns about the external and latent internally derived variables. External concepts oblige solitary as autonomous variables in the model which predict other constructs. Endogenous models, on the 
other hand, behave as dependent variables expected in a hierarchical model (Hair et al., 2013). In this analysis, sophistication, flexibility, respective benefit, the budget of implementation, administrative assistance, organizational capital, organizational scale, the effectiveness of transition, IT expertise were externally derived concepts while the implementation of e-business was endogenous. A total of 30 questions were taken from the relevant studies and updated to suit this study's e-business sense. To evaluate the responses, a 5-points Likert scale was introduced extending from "strongly disagree (1)" to "strongly agree (5). Initially, four IT professionals with at least five years of e-business experience, and two researchers reviewed the questionnaire elements for validating content. According to the experts' remarks, important improvements were made to the products. Until the full-scale analysis was conducted, the questionnaires were pilot-tested as well with twenty company group administrators to overcome any uncertainty and validate its flow.

Figure 2. Nigeria geographical zone (Dineen, et al., 2008)

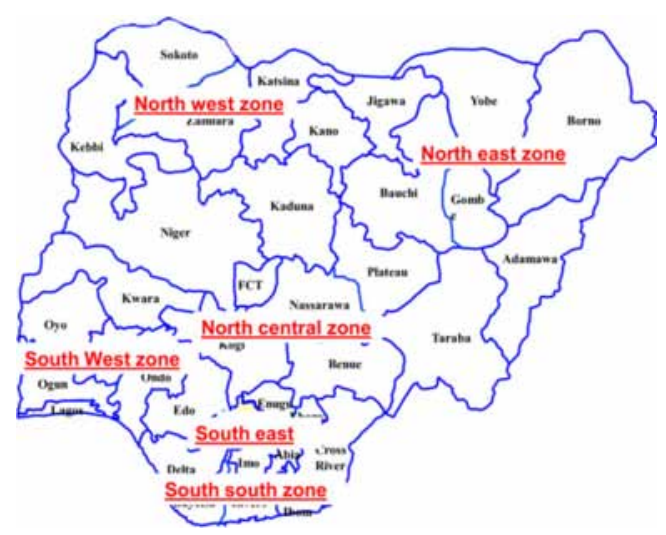

An e-mail with a direct connection to an internet investigation was developed and submitted to the respondents, and if they had any e-business channel and expertise, they were asked to complete the questionnaire. After three weeks, an email was sent to the respondents as a reminder to increase the response rate and expand community coverage. Data were compiled from April to June 2020. More than 450 questionnaires were issued, and after three months, 255 completed responses were received. Established on the utmost popular law of calculation of sample size for PLS introduced by Hair et al. (2016), the sample size needed for this analysis is at least 120 . Therefore, a minimum of 255 pieces of feedbacks obtained was satisfactory to analyze the variables of the model built.

\section{RESULTS AND DISCUSSION}

\subsection{Respondent's Profile}

The respondents' socio-economic status is summarized in Table 1. Male was the common portion of respondents $77.6 \%$ while the female was $22.4 \%$ were female. $17.6 \%$ of the respondents were less or equal to 30 years, $61.2 \%$ of respondents were in the age of $31-44$, and $21.2 \%$ were aged 45 and above. An important quota of respondents $48.2 \%$ have B.Sc. and above, $36.5 \%$ have HND while the remaining respondents have OND (15.3\%). Also, a significant number of respondents $(85.9 \%)$ have worked for more than 5 years in their respective companies. $43.9 \%$ were working in a small-sized firm, $26.7 \%$ were working in a medium-sized firm while $29.4 \%$ of them were from big-sized firms. 


\subsection{Quantity Of Questions Used to Assess The Model}

Table 2 shows the evaluation of the convergent validity and reliability of the questionnaire. A Confirmatory Factor Analysis (CFA) explores the estimation procedure in the form of sampling adequacy. The uniform CFA value indicates that all the element loadings remained greater than the recommended value of 0.70 (Chin, 1998). Thus, there is no need to delete some objects and all items are placed in the evaluation of the dimension model. Build dependability is determined using "Cronbach 's Alpha coefficient (CA)" (Cronbach, 1971) and "Composite Reliability (CR)" (Straub et al., 2004). Suitable values for CR and CA remain equivalent to or greater than 0.7 (MacKenzie et al., 2011). Though, according to Straub et al (2004) and Hair et al. (2010), CA value greater than 0.6 are also justifiable. Convergent rationality is the consistency degree of items in calculating a concept in comparison to items evaluating other variables (Urbach \& Ahlemann, 2010). According to the findings of SPSS, the loading factor for all products exceeded the value of 0.7. The CA and $\mathrm{CR}$ ranged above the appropriate values, helping build consistency. The AVE ranged from 0.569 to 0.836 , supporting the convergent rationality of the criteria.

Table 1. Socio-economic status of the respondents

\begin{tabular}{|c|c|c|c|}
\hline Characteristics & & Frequency & Percentage \\
\hline \multirow{3}{*}{ Gender } & Male & 198 & $77.6 \%$ \\
\cline { 2 - 4 } & Female & 57 & $22.4 \%$ \\
\hline \multirow{3}{*}{ Age } & $£ 30$ & 45 & $17.6 \%$ \\
\cline { 2 - 4 } & $31-44$ & 156 & $61.2 \%$ \\
\cline { 2 - 4 } & ${ }^{3} 45$ & 54 & $21.2 \%$ \\
\hline \multirow{3}{*}{ Education Level } & OND & 39 & $15.3 \%$ \\
\cline { 2 - 4 } & HND & 93 & $36.5 \%$ \\
\cline { 2 - 4 } & B.SC and above & 123 & $48.2 \%$ \\
\hline \multirow{3}{*}{ Working Experience in the Company } & $£ 4$ & 36 & $14.1 \%$ \\
\cline { 2 - 4 } & $5-9$ & 82 & $32.2 \%$ \\
\cline { 2 - 4 } & ${ }^{*} 10$ & 137 & $53.7 \%$ \\
\hline \multirow{3}{*}{ Size of Firms } & Small & 112 & $43.9 \%$ \\
\hline
\end{tabular}

\subsection{Structural Model Assessment}

The conceptual model was evaluated to test the acceptability of existing hypotheses. Table 3 displays the outcomes of the research hypotheses. Under technology assessment, usability $(\mathrm{p}<0.01)$ and comparative significance $(\mathrm{p}<0.01)$ demonstrated constructive effects on e-business implementation, endorsing $\mathrm{H} 2$, and $\mathrm{H} 3$. Thus, the outcomes of both complication $(\mathrm{p}>0.05)$ and expense of implementation ( $>0.05$ ) weren't statistically relevant, thus discarding $\mathrm{H} 1$ and $\mathrm{H} 4$. All organizational variables, leadership structure $(\mathrm{p}<0.01)$, administrative asset $(\mathrm{p}<0.01)$, and company size $(\mathrm{p}<0.05)$ revealed a strong association with e-business implementation, endorsing $\mathrm{H} 5, \mathrm{H} 6$, and $\mathrm{H} 7$. The results supported H9, connecting IT knowledge with e-business adoption $(\mathrm{p}<0.05)$. Nevertheless, there was no justification for the correlation between change effectiveness and e-business adoption $(p>0.05)$, 
Table 2. Assessment of convergent validity and reliability

\begin{tabular}{|c|c|c|c|c|}
\hline Constructs & Items & $\begin{array}{l}\text { Indicator } \\
\text { Reliability }\end{array}$ & & \\
\hline & & Factor Loading & $\begin{array}{c}\text { Cronbach's alpha } \\
\text { (CA) }\end{array}$ & $\begin{array}{c}\text { Composite } \\
\text { Reliability (CR) }\end{array}$ \\
\hline \multirow{3}{*}{ Complexity } & COM1 & 0.734 & \multirow{3}{*}{0.734} & \multirow{3}{*}{0.910} \\
\hline & COM2 & 0.708 & & \\
\hline & COM3 & 0.843 & & \\
\hline \multirow{3}{*}{ Compatibility } & COMP1 & 0.923 & \multirow{3}{*}{0.752} & \multirow{3}{*}{0.956} \\
\hline & COMP2 & 0.874 & & \\
\hline & COMP3 & 0.945 & & \\
\hline \multirow{4}{*}{ Relative important } & RI1 & 0.756 & \multirow{4}{*}{0.717} & \multirow{4}{*}{0.934} \\
\hline & RI2 & 0.712 & & \\
\hline & RI3 & 0.735 & & \\
\hline & RI4 & 0.868 & & \\
\hline \multirow{3}{*}{ Cost of Adoption } & COA1 & 0.956 & \multirow{3}{*}{0.785} & \multirow{3}{*}{0.843} \\
\hline & $\mathrm{COA} 2$ & 0.923 & & \\
\hline & COA3 & 0.845 & & \\
\hline \multirow{4}{*}{ Management Support } & MS1 & 0.769 & \multirow{4}{*}{0.701} & \multirow{4}{*}{0.818} \\
\hline & MS2 & 0.782 & & \\
\hline & MS3 & 0.739 & & \\
\hline & MS4 & 0.769 & & \\
\hline \multirow{3}{*}{ Organization Size } & OS1 & 0.789 & \multirow{3}{*}{0.754} & \multirow{3}{*}{0.809} \\
\hline & OS2 & 0.709 & & \\
\hline & OS2 & 0.964 & & \\
\hline \multirow{3}{*}{ Change Efficacy } & CE1 & 0.887 & \multirow{3}{*}{0.803} & \multirow{3}{*}{0.900} \\
\hline & CE2 & 0.933 & & \\
\hline & CE3 & 0.765 & & \\
\hline \multirow{3}{*}{ IT Expertise } & IE1 & 0.812 & \multirow{3}{*}{0.834} & \multirow{3}{*}{0.902} \\
\hline & IE2 & 0.897 & & \\
\hline & IE3 & 0.975 & & \\
\hline \multirow{4}{*}{ E-business Adoption } & EBA1 & 0.723 & \multirow{4}{*}{0.694} & \multirow[b]{4}{*}{0.809} \\
\hline & EBA2 & 0.743 & & \\
\hline & EBA3 & 0.876 & & \\
\hline & EBA4 & 0.678 & & \\
\hline \multirow{4}{*}{ Usage during COVID-19 } & UDC1 & 0.894 & \multirow{4}{*}{0.834} & \\
\hline & UDC2 & 0.829 & & \\
\hline & UDC3 & 0.867 & & \\
\hline & UDC4 & 0.765 & & \\
\hline
\end{tabular}


Table 3. Hypothesis testing results

\begin{tabular}{|c|c|c|c|c|}
\hline Hypotheses & Path Coefficient & r-value & p-value & Results \\
\hline H1: Complexity E-business adoption & -0.071 & 0.952 & $\mathrm{p}<0.05$ & Rejected \\
\hline H2: Compatibility E-business adoption & 0.128 & $2.741^{* *}$ & $\mathrm{p}<0.01$ & Accepted \\
\hline H3: Relative important E-business adoption & 0.152 & $2.792^{* *}$ & $\mathrm{p}<0.01$ & Accepted \\
\hline H4: Cost of adoption E-business adoption & -0.032 & 0.352 & $\mathrm{p}<0.05$ & Rejected \\
\hline H5: Management support E-business adoption & 0.139 & $2.514^{* *}$ & $\mathrm{p}<0.01$ & Accepted \\
\hline H6: Organization resource E-business adoption & 0.134 & $2.614^{* *}$ & $\mathrm{p}<0.01$ & Accepted \\
\hline H7: Organization size E-business adoption & 0.084 & 1.816 & $\mathrm{p}<0.05$ & Rejected \\
\hline H8: Change efficacy E-business adoption & 0.013 & 0.147 & $\mathrm{p}<0.05$ & Rejected \\
\hline H9: IT expertise E-business adoption & 0.124 & $1.796^{*}$ & $\mathrm{p}<0.05$ & Accepted \\
\hline H10: E-business adoption Usage during & & & & Accepted \\
\hline
\end{tabular}

Note: ${ }^{*} p<0.05,{ }^{* *} p<0.01,{ }^{* * *} p<0.001$

which rejects H8. In particular, the results verified the positive and important impact of e-business adoption during COVID-19 on organization services and sales $(\mathrm{p}<0.001)$, therefore endorsing H10. $\mathrm{R} 2$ values of e-business implementation (0.517) and services and sales during COVID-19 (0.715) indicate which prototype has a better prediction overall accuracy (Hair et al., 2016). It indicates that 51.7 percent of the variance for e-business implementation and 71.5 percent of the variance in company services and sales during COVID-19 are explained by the model.

Therefore, the development of an e-business implementation system by combining TOE and HOT systems is the key involvement of this research. Mostly, evaluating the important factors that influence the adoption and defining their preferences in forecasting e-business acceptance and company services and sales during COVID-19. According to the results, perceived usefulness is the most important acceptance issue under technology calculation. This conclusion is confirmed by (Brock and Khan, 2017; Shin, 2016; Verma, 2017). E-business provides huge benefits to companies and firms in the form of pricing, service delivery, improved decision-making, cost reduction of ads, risk assessment, and generating revenue (Shin, 2016). There is no reasoning motivation to embrace and use e-business in companies without identifying its relative essential (Park et al., 2015). The discoveries also indicated that usability is the second crucial technical feature, which clarified the observations of (Sun et al., 2016; Verma et al., 2017). According to Rogers (2003), both the technological and business feasibility of a new product are significant factors affecting the implementation of e-business.

Programs excellently matched with existing tools and methods are implemented more rapidly than those which are not (Shin, 2016). Management support became the most significant implementation influence in the company scope. This finding was followed by other studies including (Brock \& Khan, 2017; Verma et al., 2017). The critical part of great executives in distributing assets and creating a positive firm atmosphere will substantially accelerate the adoption of technologies (Hung et al., 2016). This study identified operational capital and company scope as the second and third essential elements beneath the firm aspect. The presence of sufficient financial, human, and technical resources will greatly promote the cycle of invention implementation (Hameed et al., 2012). A business with better capital can implement new technology faster (Kwon et al., 2014). The size of the firm is regarded as a major business asset for implementing innovation (Wang et al., 2010).

By specific, bigger organizations are designed by a broader variety of capital and are open to taking more chances. Therefore, they are required to promote the implementation and development of new IT (Zhu et al., 2006b). IT competence was discovered to become the only valuable social- 
dimensional influencing factor. Deploying highly trained human capital that can be actively engaged in the implementation of IT technology is essential for all organizations (Maduku et al., 2016). Lower levels of qualified workers willing to use technology would adversely affect the behavioral intent of companies to use the application (Ghobakhloo et al., 2012). Besides, there must be sufficient IT personnel with the necessary knowledge and skills in terms of eBusiness implementation and use in companies (Sun et al., 2016). Ultimately, a strong correlation was endorsed during COVID-19 between eBusiness implementation and company sales and services. While no researchers work on similar results in terms of e-business adoption, previous research has provided clear evidence for the positive impact of the adoption of innovation on company effectiveness (Garrison et al., 2015; Voola et al., 2012). Global businesses have started striving to increase their sales and marketing through the use of e-business platforms particularly during COVID-19 (Kang \& Kim, 2015). Smart use of E-Business will dramatically boost the sales and service delivery of a business to its customers.

Many businesses were forced to continue operating during the COVID-19 crisis. Pharmaceutical, medicinal equipment, and medical instruments industries, sterilization, disinfection, and cleaning materials industries, and many others, most notably the food industry, are examples of these important industries. As a result, these sectors are appealing for research into e-business preparedness in pandemics. As a result of the pandemic's pressures, society pursued digital solutions. Governments and public administrations have taken significant steps to resolve this issue (Haroon \& Rizvi, 2020). E-business adoption has become critical to enabling businesses and approved applications to meet citizens' basic needs and deliver products to their homes. Furthermore, the government unveiled online platforms and apps to provide people and companies with essential services, allowing all to use e-payment systems and mobile e-wallet services (Al-Omoush et al., 2020).

According to the results, e-business and collective information building have a direct positive effect on an organization's ability to react quickly to the COVID-19 crisis. Thanks to the extreme stresses of the COVID-19 pandemic, business operations, and practices have been interrupted. The pandemic has put a survival rule on businesses: "No e-business, no job". As businesses aim to meet consumers' emergency needs, the coronavirus pandemic has sparked a new wave of e-business developments. Organizations that used e-business as a secondary channel of doing business have been forced to reprioritize their processes and practices against creative e-business solutions as a result of the COVID-19 outbreak (Al-Omoush et al, 2020).

\section{CONCLUSION}

The spread of Covid-19 in a real sense is a result of the digital and technological transition that has changed the world we live in, in the last century. To continue to work, private businesses and higher education institutions have made an abrupt transition to online video conferencing and other automated solutions, while the health care system continues to address this problem primarily through costly brick-and-mortar visits. It is predicted that COVID-19 could cost the world more than $\$ 10$ trillion, but there is significant uncertainty about the virus's spread and the efficiency of the policy response. More than 10 million people worldwide are plunged into poverty for a rising percentage point drop in the global economy. Given that chronic illnesses will affect the poorest populations more, and they will also be exposed to a high risk of COVID-19 with a high mortality rate. As the most up-todate technical advancement, e-business has attracted ever greater interest from managers in various enterprises. Although e-business has several opportunities for companies, its implementation is still in the first phases and this modern concept is still not being fully used by many companies. Limit number of studies were conducted to identify important factors affecting e-business acceptance and company sales and services. This study established an interdisciplinary model to examine the important factors of e-business implementation from the viewpoint of technology, organization, and people. This research explicitly examined how e-business implementation during COVID-19 would lead to increases in company sales and services. The findings showed that sophistication, cost of 
implementation, and effectiveness shift had no significant effects in forecasting the implementation of e-business. However, the most important indicator of e-business adoption and firm sales and services during COVID-19 is the consumption of a good under the technology influence. Compatibility, relative importance, management support, and IT expertise substantial forecaster of e-business implementation and company sales and services during COVID-19. As the pandemic has caused an increased economic recession, the unemployment rate will increase significantly and health and social inequality are further threatened by welfare networks. Therefore, e-business is very important for the continuous operations of companies and businesses during the COVID-19 outbreak.

\section{ACKNOWLEDGMENT}

The authors want to acknowledge the contribution of the late Mr. Kolawole Paul Oluwatoba. 


\section{REFERENCES}

Abdin, M. D. (2020). Doing businesses during the Covid-19 crisis and afterward. Academic Press.

Agarwal, R., \& Prasad, J. (1998). A conceptual and operational definition of personal innovativeness in the domain of information technology. Information Systems Research, 9(2), 204-215. doi:10.1287/isre.9.2.204

Ahani, A., Rahim, N. Z. A., \& Nilashi, M. (2017). Forecasting social CRM adoption in SMEs: A combined SEM-neural network method. Computers in Human Behavior, 75, 560-578. doi:10.1016/j.chb.2017.05.032

Ahmadi, H., Nilashi, M., \& Ibrahim, O. (2015). Organizational decision to adopt hospital information system: An empirical investigation in the case of Malaysian public hospitals. International Journal of Medical Informatics, 84(3), 166-188. doi:10.1016/j.ijmedinf.2014.12.004 PMID:25612792

Ajzen, I. (1991). The theory of planned behavior. Organizational Behavior and Human Decision Processes, 50(2), 179-211. doi:10.1016/0749-5978(91)90020-T

Akter, S., Wamba, S. F., Gunasekaran, A., Dubey, R., \& Childe, S. J. (2016). How to improve firm performance using big data analytics capability and business strategy alignment? International Journal of Production Economics, 182, 113-131. doi:10.1016/j.jppe.2016.08.018

Al-Natour, S., \& Benbasat, I. (2009). The adoption and IT artefacts: A new interaction-centric model for the study of user artefact relationships. Journal of the Association for Information Systems, 10(9), 661-685. doi:10.17705/1jais.00208

Al-Omoush, K. S., Simón-Moya, V., \& Sendra-García, J. (2020). The impact of social capital and collaborative knowledge creation on e-business proactiveness and organizational agility in responding to the COVID-19 crisis. Journal of Innovation \& Knowledge, 5(4), 279-288. doi:10.1016/j.jik.2020.10.002

Awa, H., Baridam, D., \& Nwibere, B. (2015). Demographic determinants of e-commerce adoption: A twist by location factors. Journal of Enterprise Information Management, 28(3), 325-346. doi:10.1108/JEIM-10-20130073

Awa, H. O., Ukoha, O., \& Emecheta, B. C. (2016). Using TOE theoretical framework to study the adoption of ERP solution. Cogent Business \& Management, 3(1), 1196571. doi:10.1080/23311975.2016.1196571

Baker, J. (2012). The technology-organization-environment framework. In Information systems theory. Springer.

Barrett, M., Grant, D., \& Wailes, N. (2006). ICT and organizational change: Introduction to the special issue. The Journal of Applied Behavioral Science, 42(1), 6-22. doi:10.1177/0021886305285299

Beleščák, D. (2014). Vytváříme e-shop veWordPressupomocíWooCommerce (1st ed.). Computer Press.

Blumberg, B. F., Cooper, D. R., \& Schindler, P. S. (2014). Business research methods. McGraw-Hill Education.

Brock, V., \& Khan, H. U. (2017). Big data analytics: Does organizational factor matters impact technology acceptance? Journal of Big Data, 4(1), 21. doi:10.1186/s40537-017-0081-8

Cantú, E. P., Morejón, V., Molinaand, M., \& Wong, A. M. (2014). Gestión e impactodelcomercioelectrónico EN el rendimientoempresarial [E-business management impact in business performance]. Institute for Business \& Finance Research ProQuest Central.

Cohen, J., \&Kupferschmidt, K. (2020). Strategies shift as coronavirus pandemic looms. Academic Press.

Daniyal, M., Ogundokun, R. O., Abid, K., Khan, M. D., \& Ogundokun, O. E. (2020). Predictive modeling of COVID-19 death cases in Pakistan. Infectious Disease Modelling, 5, 897-904. doi:10.1016/j.idm.2020.10.011 PMID:33195884

Dholakia, R. R., \& Uusitalo, O. (2002). Switching to electronic stores: Consumer characteristics and the perception of shopping benefits. International Journal of Retail \& Distribution Management, 30(10), 459-469. doi: $10.1108 / 09590550210445335$

Dineen, B., Gilbert, C. E., Rabiu, M., Kyari, F., Mahdi, A. M., Abubakar, T., \& Faal, H. et al. (2008). The Nigerian national blindness and visual impairment survey: Rationale, objectives, and detailed methodology. BMC Ophthalmology, 8(1), 17. doi:10.1186/1471-2415-8-17 PMID:18808712 
Dwivedi, Y. K., Papazafeiropoulo, A., Shiau, W. L., Hsu, P. Y., \& Wang, J. Z. (2009). Development of measures to assess the ERP adoption of small and medium enterprises. Journal of Enterprise Information Management.

Gangwar, H., Date, H., \& Raoot, A. (2014). Review on IT adoption: Insights from recent technologies. Journal of Enterprise Information Management, 27(4), 488-502. doi:10.1108/JEIM-08-2012-0047

Gangwar, H., Date, H., \& Raoot, A. D. (2014). Review on IT adoption: Insights from recent technologies. Journal of Enterprise Information Management, 27(4), 488-502. doi:10.1108/JEIM-08-2012-0047

Garrison, G., Wakefield, R. L., \& Kim, S. (2015). The effects of IT capabilities and delivery model on cloud computing success and firm performance for cloud supported processes and operations. International Journal of Information Management, 35(4), 377-393. doi:10.1016/j.jinfomgt.2015.03.001

Ghobakhloo, M., Hong, T. S., Sabouri, M. S., \& Zulkifli, N. (2012). Strategies for successful information technology adoption in small and medium-sized enterprises. Information (Basel), 3(1), 36-67. doi:10.3390/ info3010036

Hair, J. F. Jr, Hult, G. T. M., Ringle, C., \& Sarstedt, M. (2016). A primer on partial least squares structural equation modeling (PLS-SEM). Sage publications.

Hameed, M. A., Counsell, S., \& Swift, S. (2012). A meta-analysis of relationships between organizational characteristics and IT innovation adoption in organizations. Information \& Management, 49(5), 218-232. doi:10.1016/j.im.2012.05.002

Haroon, O., \& Rizvi, S. A. R. (2020). Flatten the curve and stock market liquidity-an inquiry into emerging economies. Emerging Markets Finance \& Trade, 56(10), 2151-2161. doi:10.1080/1540496X.2020.1784716

Henriksen, H. Z. (2006). Motivators for IOS adoption in Denmark. Journal of Electronic Commerce in Organizations, 4(2), 25-39. doi:10.4018/jeco.2006040102

Hong, S., Thong, J. Y., \& Tam, K. Y. (2006). Understanding continued information technology usage behavior: A comparison of three models in the context of mobile internet. Decision Support Systems, 42(3), 1819-1834. doi:10.1016/j.dss.2006.03.009

Hong, W., \& Zhu, K. (2006). Migrating to internet-based e-commerce: Factors affecting e-commerce adoption and migration at the firm level. Information \& Management, 43(2), 204-221. doi:10.1016/j.im.2005.06.003

Horch, A., Wohlfrom, A., \& Weisbecker, A. (2017). An E-shop analysis wif a focus on product data extraction. In D. Bridge \& H. Stuckenschmidt (Eds.), E-business and web technologies. Lecture notes in business information processing (Vol. 278, pp. 61-72). Springer.

Jacobsson, M., \& Linderoth, H. (2010). The influence of contextual elements, actors' frames of reference, and technology on the adoption and use of ICT in construction projects: A Swedish case study. Construction Management and Economics, 28(1), 13-23. doi:10.1080/01446190903406154

Kapoor, K. K., Dwivedi, Y. K., \& Williams, M. D. (2014). Rogers' innovation adoption attributes A systematic review and synthesis of existing research. Information Systems Management, 31(1), 74-91. doi:10.1080/1058 0530.2014 .854103

Kartiwi, M., Hussin, H., Suhaimi, M. A., Jalaldeen, M. R. M., \& Amin, M. R. (2018). Impact of external factors on determining E-business benefits among SMEs in Malaysia. Journal of Global Entrepreneurship Research, 8(1), 18. Advance online publication. doi:10.1186/s40497-018-0105-7

Kollmann, T., Lomberg, C., \& Peschl, A. (2016). Web 1.0, Web 2.0, and Web 3.0: The development of e-business. Encyclopedia of E-business Development, Implementation, and Management, 10. DOI: doi:10.4018/978-14666-9787-4.ch081

Kuan, K. K., \& Chau, P. Y. (2001). A perception-based model for EDI adoption in small businesses using a technology-organization-environment framework. Information \& Management, 38(8), 507-521. doi:10.1016/ S0378-7206(01)00073-8

Kwon, O., Lee, N., \& Shin, B. (2014). Data quality management, data usage experience, and acquisition intention of big data analytics. International Journal of Information Management, 34(3), 387-394. doi:10.1016/j. ijinfomgt.2014.02.002 
Lian, J. W., Yen, D. C., \& Wang, Y. T. (2014). An exploratory study to understand the critical factors affecting the decision to adopt cloud computing in Taiwan hospital. International Journal of Information Management, 34(1), 28-36. doi:10.1016/j.ijinfomgt.2013.09.004

Lu, H. P., \& Yang, Y. W. (2014). Toward an understanding of the behavioral intention to use a social networking site: An extension of task-technology fit to social-technology fit. Computers in Human Behavior, 34, 323-332. doi:10.1016/j.chb.2013.10.020

Lucchetti, R., \& Sterlacchini, A. (2004). The adoption of ICT among SMEs: Evidence from an Italian survey. Small Business Economics, 23(2), 151-168. doi:10.1023/B:SBEJ.0000027667.55821.53

Lukman, A. F., Rauf, R. I., Abiodun, O., Oludoun, O., Ayinde, K., \& Ogundokun, R. O. (2020). COVID-19 prevalence estimation: Four most affected African countries. Infectious Disease Modelling, 5, 827-838. doi:10.1016/j.idm.2020.10.002 PMID:33073068

Maduku, D. K., Mpinganjira, M., \& Duh, H. (2016). Understanding mobile marketing adoption intention by South African SMEs: A multi-perspective framework. International Journal of Information Management, 36(5), 711-723. doi:10.1016/j.ijinfomgt.2016.04.018

Moore, G., \& Benbasat, I. (1991). Development of an instrument to measure the perceptions of adopting an information technology innovation. Information Systems Research, 2(3), 192-222. doi:10.1287/isre.2.3.192

Nam, D. W., Kang, D. W., \& Kim, S. (2015, January). Process of big data analysis adoption: Defining big data as a new IS innovation and examining factors affecting the process. In 2015 48th Hawaii International Conference on System Sciences (pp. 4792-4801). IEEE.

Nilashi, M., Ahmadi, H., Ahani, A., Ravangard, R., \& Ibrahim, O. (2016). Determining the importance of hospital information system adoption factors using a fuzzy analytic network process (ANP). Technological Forecasting and Social Change, 111, 244-264. doi:10.1016/j.techfore.2016.07.008

OdomJ. G. (2020). COVID-19 and the Law: A Compilation of Legal Resources. Available at SSRN 3588225.

Ogundokun, R. O., Lukman, A. F., Kibria, G. B. M., Awotunde, J. B., \& Aladeitan, B. B. (2020). Predictive modelling of COVID-19 confirmed cases in Nigeria. Infectious Disease Modelling, 5, 543-548. doi:10.1016/j. idm.2020.08.003 PMID:32835145

Oliveira, T., \& Martins, M. F. (2011). Literature review of information technology adoption models at a firm level. Electronic Journal of Information Systems Evaluation, 14(1), 110.

Pan, M. J., \& Jang, W. Y. (2008). Determinants of the adoption of enterprise resource planning within the technology-organization-environment framework: Taiwan's communications industry. Journal of Computer Information Systems, 48(3), 94-102.

Park, J. H., Kim, M. K., \& Paik, J. H. (2015). The factors of technology, organization, and environment influencing the adoption and usage of big data in Korean firms. Academic Press.

Petter, S., DeLone, W., \& McLean, E. R. (2013). Information systems success: The quest for the independent variables. Journal of Management Information Systems, 29(4), 7-62. doi:10.2753/MIS0742-1222290401

Pilík, M. (2013). Selected factors influencing customers' behavior in E-business on B2C markets in the Czech Republic. In Proceedings of the European Conference on IS Management \& Evaluation (pp. 121-128). University of Gdańsk.

Pinsonneault, A., \& Kraemer, K. (1993). Survey research methodology in management information systems: An assessment. Journal of Management Information Systems, 10(2), 75-105. doi:10.1080/07421222.1993.11518001

Powell, T. C., \& Dent-Micallef, A. (1997). Information technology as a competitive advantage: The role of human, business, and technology resources. Strategic Management Journal, 18(5), 375-405. doi:10.1002/ (SICI)1097-0266(199705)18:5<375::AID-SMJ876>3.0.CO;2-7

Ramamurthy, K. R., Sen, A., \& Sinha, A. P. (2008). An empirical investigation of the key determinants of data warehouse adoption. Decision Support Systems, 44(4), 817-841. doi:10.1016/j.dss.2007.10.006

Rogers, E. M. (2003). Diffusion of innovations. Free Press. 
Rogers, E. M., Singhal, A., \& Quinlan, M. M. (2019). Diffusion of innovations 1. In An integrated approach to communication theory and research (pp. 415-434). Routledge. doi:10.4324/9780203710753-35

Romm, J., Rosenfeld, A., \& Herrmann, S. (1999). The internet economy and global warming. The Center for Energy and Climate Solutions.

Salwani, M., Marthandan, G., Norzaidi, M., \& Chong, S. (2009). E-commerce usage and business performance in the Malaysian tourism sector: Empirical analysis. Information Management \& Computer Security, 17(2), 166-185. doi:10.1108/09685220910964027

Shahzad, A., Chan, H. K., Altaf, M., \& Anwar, F. (2020). Malaysian SMEs Performance and the use of E-Commerce: A Multi-Group Analysis of Click-and-Mortar and Pure-Play E-Retailers. Pakistan Journal of Commerce and Social Sciences, 14(1), 1-33.

Shin, D. H. (2016). Demystifying big data: Anatomy of big data developmental process. Telecommunications Policy, 40(9), 837-854. doi:10.1016/j.telpol.2015.03.007

Soon, K. W. K., Lee, C. A., \& Boursier, P. (2016). A study of the determinants affecting the adoption of big data using integrated technology acceptance model (TAM) and diffusion of innovation (DOI) in Malaysia. International Journal of Applied Business and Economic Research, 14(1), 17-47.

Sun, S., Cegielski, C. G., Jia, L., \& Hall, D. J. (2018). Understanding the factors affecting the organizational adoption of big data. Journal of Computer Information Systems, 58(3), 193-203. doi:10.1080/08874417.201 6.1222891

Tornatzky, L. G., Fleischer, M., \& Chakrabarti, A. K. (1990). Processes of technological innovation. Lexington Books.

Turban, E., King, D., Lee, J. K., Liang, T. P., \& Turban, D. C. (2015). Electronic Commerce: A Managerial and Social Networks Perspective (8th ed.). Springer International Publishing. ISBN 978-3-319-10091-3. DOI: doi:10.1007/978-3-319-10091-3

Venkatesh, V., \& Bala, H. (2008). Technology acceptance model 3 and a research agenda on interventions. Decision Sciences, 39(2), 273-315. doi:10.1111/j.1540-5915.2008.00192.x

Verma, S., \& Bhattacharyya, S. S. (2017). Perceived strategic value-based adoption of Big Data Analytics in an emerging economy. Journal of Enterprise Information Management, 30(3), 354-382. doi:10.1108/JEIM10-2015-0099

Voola, R., Casimir, G., Carlson, J., \& Agnihotri, M. A. (2012). The effects of market orientation, technological opportunism, and e-business adoption on performance: A moderated mediation analysis. Australasian Marketing Journal, 20(2), 136-146. doi:10.1016/j.ausmj.2011.10.001

Wang, Y., Wang, Y., \& Yang, Y. (2010). Understanding the determinants of RFID adoption in the manufacturing industry. Technological Forecasting and Social Change, 77(5), 803-815. doi:10.1016/j.techfore.2010.03.006

Wang, Y. S., Li, H. T., Li, C. R., \& Zhang, D. Z. (2016). Factors affecting hotels' adoption of mobile reservation systems: A technology-organization-environment framework. Tourism Management, 53, 163-172. doi:10.1016/j. tourman.2015.09.021

Weiner, B. J., Amick, H., \& Lee, S. Y. D. (2008). Conceptualization and measurement of organizational readiness for change: A review of the literature in health services research and other fields. Medical Care Research and Review: MCRR, 65(4), 379-436. doi:10.1177/1077558708317802 PMID:18511812

Wen, K. W., \& Chen, Y. (2010). E-business value creation in Small and Medium Enterprises: A US study using the TOE framework. International Journal of Electronic Business, 8(1), 80-100. doi:10.1504/IJEB.2010.030717

Yoon, T. E., \& George, J. F. (2013). Why aren't organizations adopting virtual worlds? Computers in Human Behavior, 29(3), 772-790. doi:10.1016/j.chb.2012.12.003

Zepeda, L. (1994). The simultaneity of technology adoption and productivity. Journal of Agricultural and Resource Economics, 46-57. 
Zheng, S., Yen, D. C., \& Tarn, J. M. (2000). The new spectrum of the cross-enterprise solution: The integration of supply chain management and enterprise resources planning systems. Journal of Computer Information Systems, 41(1), 84-93.

Zhu, K., \& Kraemer, K. L. (2002). E-commerce metrics for net-enhanced organizations: Assessing the value of e-commerce to firm performance in the manufacturing sector. Information Systems Research, 13(3), 275-295. doi:10.1287/isre.13.3.275.82 
APPENDIX A.

Table 4. Measurement items and the constructs

\begin{tabular}{|c|c|c|}
\hline Construct & Code & Measurement items \\
\hline \multirow{3}{*}{ Complexity } & COMPL1 & $\begin{array}{l}\text { Our company's social networks and membership with industrial and trade bodies enhance the opportunities for } \\
\text { acquiring cutting-edge ideas and insights. }\end{array}$ \\
\hline & COMPL2 & Our company has close connections and collective actions with its business partners \\
\hline & COMPL3 & Our business partners effectively participate in deciding on the matters that affect them. \\
\hline \multirow{5}{*}{ Compatibility } & \multicolumn{2}{|r|}{ Perceived reliability has a favorable impact on the adoption of e-Business: } \\
\hline & COMPA1 & E-business is compatible with the firm's IT infrastructure \\
\hline & COMPA2 & E-business is consistent with the firm's beliefs and values \\
\hline & COMPA3 & E-business is consistent with the firm's business strategy \\
\hline & COMPA4 & E-business is compatible with the data captured at our firms \\
\hline \multirow{5}{*}{$\begin{array}{c}\text { Relative } \\
\text { advantage }\end{array}$} & \multicolumn{2}{|r|}{ Relative benefits have constructive impacts on e-business adoption } \\
\hline & RA1 & Introducing new IT applications in responding to the effects of the COVID-19 crisis. \\
\hline & RA2 & Reinforcing the activities of exploiting innovative e-business solutions in responding to the COVID-19 crisis. \\
\hline & RA3 & Endeavoring to adopt new e-business applications during the COVID-19 crisis. \\
\hline & RA4 & $\begin{array}{l}\text { Being at the forefront of discovering emerging e-business opportunities to address restrictions imposed by the } \\
\text { coronavirus pandemic. }\end{array}$ \\
\hline \multirow{4}{*}{ Cost of adoption } & \multicolumn{2}{|r|}{ Adoption costs have a detrimental impact on the embrace of E-business } \\
\hline & CA1 & The costs involved in the adoption of e-business would be far greater than the expected benefits. \\
\hline & CA2 & The cost of maintaining an e-business would be very high for our enterprises. \\
\hline & CA3 & The cost involved in providing support systems for e-business would be too high. \\
\hline \multirow{4}{*}{$\begin{array}{l}\text { Management } \\
\text { support }\end{array}$} & \multicolumn{2}{|r|}{ Support from management has a positive impact on e-business adoption } \\
\hline & MS1 & Top management believes that investment and expenditure in this technology is worthwhile \\
\hline & MS2 & Top management believes that this technology has potential strategic value \\
\hline & MS3 & Top management believes it is important to provide the resources for our firms to adopt this technology \\
\hline \multirow{5}{*}{$\begin{array}{l}\text { Organizational } \\
\text { resources }\end{array}$} & \multicolumn{2}{|r|}{ Organizational tools have a beneficial impact on the implementation of e-Business } \\
\hline & OR1 & Our firm has the technological resources to adopt e-business \\
\hline & OR2 & Our firm has the financial resources to adopt e-business \\
\hline & OR3 & Our firm has no difficulties in finding all the necessary resources to adopt e-business \\
\hline & OR4 & Our firm has IT employees that can learn and apply new information technology rapidly \\
\hline \multirow{4}{*}{ Organization size } & \multicolumn{2}{|r|}{ The size of a company has a favorable impact on e-commerce adoption } \\
\hline & OS1 & The capital of our firm is high compared to the industry \\
\hline & OS2 & The revenue of our firm is high compared to the industry \\
\hline & OS3 & The number of employees at our firm is high compared to the industry \\
\hline \multirow{4}{*}{ External pressure } & \multicolumn{2}{|r|}{ Changing the use of e-business has a positive impact on the adoption } \\
\hline & EP1 & Our choice to adopt e-business would be strongly influenced by what competitors in the industry are doing \\
\hline & EP2 & Many of our partners would expect our hotel to adopt e-business \\
\hline & EP3 & Our relationship with our major partners would suffer if we did not adopt e-business \\
\hline \multirow{5}{*}{ IT expertise } & \multicolumn{2}{|r|}{ IT expertise has a beneficial impact on the implementation of e-business } \\
\hline & ITE1 & Our IT employees have equal or better technical knowledge than our competitors. \\
\hline & ITE2 & Our IT employees can quickly learn and apply new information technologies \\
\hline & ITE3 & Our IT employees have the skills and knowledge to manage e-business in the current business environment \\
\hline & ITE4 & Our IT employees understand the development priorities required to achieve the organizational goals. \\
\hline \multirow{5}{*}{$\begin{array}{l}\text { E-business } \\
\text { adoption }\end{array}$} & \multicolumn{2}{|r|}{ E-business adoption and utilization have a positive effect on firm services and sales } \\
\hline & BDA1 & Our firm intends to adopt e-business \\
\hline & BDA2 & Our firm intends to start using e-business regularly in the future \\
\hline & BDA3 & Our firm would highly recommend e-business for other enterprises to adopt \\
\hline & BDA4 & Our firm plans to use e-business in the next few months \\
\hline
\end{tabular}


Joseph Bamidele Awotunde (Ph.D.) is a Lecturer at the Department of Computer Science, Faculty of Communication and Information Sciences, University of Ilorin, Ilorin, Nigeria. He received the B. Tech. Mathematics/Computer Science from the Federal University of Technology, Minna, Nigeria Ph.D. and M.Sc. degrees in Computer Science from the University of Ilorin, Ilorin, Nigeria. He is the author or co-author of more than 30 papers in some international, National, and local refereed journals and conference contributions. His research interest includes Social Computing, Biometrics, Artificial Intelligence, Information Security, and Information Science.

Roseline Oluwaseun Ogundokun is a Lecturer at the Department of Computer Science, College of Pure and Applied Sciences, Landmark University, Omu Aran, Kwara State, Nigeria. She holds a Bachelor of Science in Management Information System from Covenant University, Ota; a Master of Science in Computer Science from the University of Ilorin, Ilorin. As of 2020, she is number 175 in SciVal (SCOPUS-Elsevier) analysis in Nigeria. She has published around 61 articles (SCOPUS/WoS) with over 40 coauthors from around the world in the core area of Computer Science. Her research interests include Machine learning, Steganography, and Cryptography, Information Security, Artificial Intelligence.

Abidemi Emmanuel Adeniyi is a Technologist in the Department of Computer Science, College of Pure and Applied Sciences, Landmark University, Omu-Aran, Nigeria. He received a Bachelor of Science in Computer Science from Ladoke Akintola University of Technology, Ogbomosho. His area of research includes Computer Security, Data Mining.

Sanjay Misra is editor in chief of the International Journal of Human Capital and Information Technology Professionals (IJHCITP)-IGI Global, a book series IT Personnel and Project Management, and of 3 journals (IJ). He is a Full Professor of Computer Engineering at) Covenant University (400-500 ranked University by THE) Ota, Nigeria. He has 25 years of wide experience in academic administration and research in various universities in Asia, Europe, and Africa. He is PhD. in Information and Knows. Engg (Software Engineering) from the University of Alcala, Spain, and M.Tech.(Software Engineering) from Motilal Nehru National Institute of Technology, India. As of today (15.03.2021)- As per SciVal(SCOPUS- Elsevier) analysis)- He is the most productive researcher (no. 1-) in whole Nigeria during 2012-2017, 2013-2018,2014-2019 and 2015-2020(in all subjects), in computer science no 1 in the whole country and no 2 in the whole continent. Total around 500 articles (SCOPUS/Web of Science) with 400 coauthors around the world (-105 in JCR/SCIE Journals) in the core \& application area of Software Engg (SQA, SPI, SPM), Web engg, Health Informatics, Intelligent systems, etc. He has delivered more than 80 keynote speeches/invited talks/public lectures in reputed conferences and institutes around the world (traveled around 60 countries). He got several awards for outstanding publications (2014 IET Software Premium Award (UK)), and from TUBITAK-Turkish Higher Education, and Atilim University). He edited (with colleagues) 49 LNCS \& 7 IEEE proceedings, several books, and editor in various SCIE journals.

Ajamu Gbemisola Janet is a non-teaching staff, College of Agricultural Sciences, Landmark University, Omu-Aran, Kwara State. She is a member of the Agricultural Extension Society of Nigeria (AESON) and Ph.D. Student, Department of Agricultural Extension and Rural Development University of Ilorin, Ilorin Nigeria. Her research interest are Information Communication Technology in Agricultural Extension and Community Development. 